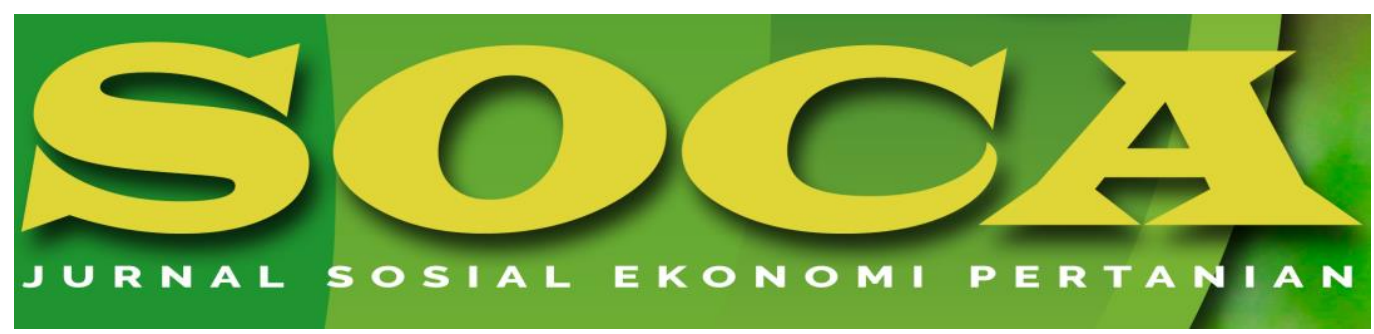

https://ojs.unud.ac.id/index.php/soca

\title{
The Development of Community-Based Ecotourism in Border Area of Sambas Regency
}

\author{
Herlina, Eva Dolorosa and Dewi Kurniati \\ Agribusiness Department, Agricultural Faculty, Tanjungpura University, Pontianak, West \\ Borneo \\ Email:herlinajulinda@gmail.com,eva.dolorosa@faperta.untan.ac.id \\ dewikurniati@faperta.untan.ac.id \\ Handphone: 085386275667, 08125700889, 08115747711
}

Submitted: January 27th 2020; Revised: February 12th, 2020; Accepted: March 19th, 2020

\begin{tabular}{l}
\hline Keywords: \\
Ecotourism; \\
Area; \\
Border Area; \\
Environment; \\
AHP
\end{tabular}

\section{Keywords:}

Abstract
Community-based ecotourism is a strategy done to develop an
area through the improvement of the tourism sector by offering
natural tourism sites that preserving the environment and
involving the community skill in managing the tourism activities.
This study aimed to identify the development of the community-
based ecotourism in the border area of Sambas Regency. There
were 30 key participants involved in this study. A questionnaire
consisted of four main criteria (environmental, economy, social,
and facility) employed in this study which then analyzed by the
AHP technique. Statistical analysis showed that the economy
criteria was having the highest weight with a total of 0.535 ,
followed by the environmental, facility, and social criteria with a
total of $0.287,0.105$, and 0.074 respectively. There were three
alternatives of community-based ecotourism analyzed to
improve the community income: beach, turtle, and mangrove
ecotourism. The statistical analysis showed that beach
ecotourism gained the highest score to be placed as an
alternative priority (0.593).

How to Cite (APA $6^{\text {th }}$ Style):

Herlina, Dolorosa, E., \& Kurniati, D. (2020). The Development of Community-Based Ecotourism in Border Area of Sambas Regency. SOCA: Jurnal Sosial Ekonomi Pertanian, 14(3), 485-498. https://doi.org/https://doi.org/10.24843/SOCA.2020.v14.i03.p10 


\section{INTRODUCTION}

Today, most people spent their leisure time by visiting various tourism sites. (Naisbitt \& Jhon, 1994) stated that in the year of 2000 the tourism industry would highly contribute to the national income. A regulation issued by the National Minister of Home Affairs (Regulation No. 33 year 2009) about the Local Ecotourism Development Guideline stated that ecotourism as a local top economic sector hasn't fully developed, even though it has a significant role in preserving the environment and cultural aspect in an area.

Community-based ecotourism was the initial step taken to improve the ecotourism site by actively involving the community on its management and development. This type of ecotourism mainly aimed to create community wellness. Parallel with a study done by (Qomariah, 2009), community-based ecotourism defined as a type of educative ecotourism and actively involving the community in planning, decision making, and sharing the economic profit. The profit-shared by the community done based on the agreement made between the tourism site management parties and the community.

West Borneo has abundances of natural beauty that potentially supporting the local economy security and community wellness if it well managed. Paloh district is a coastal area located in the Sambas Regency and a district in West Borneo that directly terrestrial and aquatically situated in the border area between Indonesia and Serawak, Malaysia. The tourism sites provided by Paloh district usually characterized by the uniqueness of its nature and ecotourism that highly rich in biological diversity (beaches, turtle species). Paloh District also known as "heaven in the tail of Borneo" or "Surga di Ekor Borneo" in Bahasa Indonesia.

Community-based ecotourism is a concept utilized to develop ecotourism which consisted of the plan, implementation, and the management system involving the benefit that would be accepted by the community. Ecotourism is also providing a wide range of job vacancies for the community around the site such as microindustry workers, souvenir sellers, transportation providers, homestay owners, guides, etc. This community-based ecotourism has positively affected the preservation of the nature and local culture, improving the income, reducing the community poverty, and improving the site's infrastructures which could increase the ecotourism activities in the end. The ecotourism sites in the border area of Sambas Regency were offering unique and attractive landscapes. Unfortunately, these sites did not fully optimized as ecotourism sites, hence it could not contribute significantly to preserve the environment and the wellness of the community. Therefore, this study done to identify the priority alternative in developing community based-ecotourism in the border area of Sambas Regency. 


\section{RESEARCH METHODS}

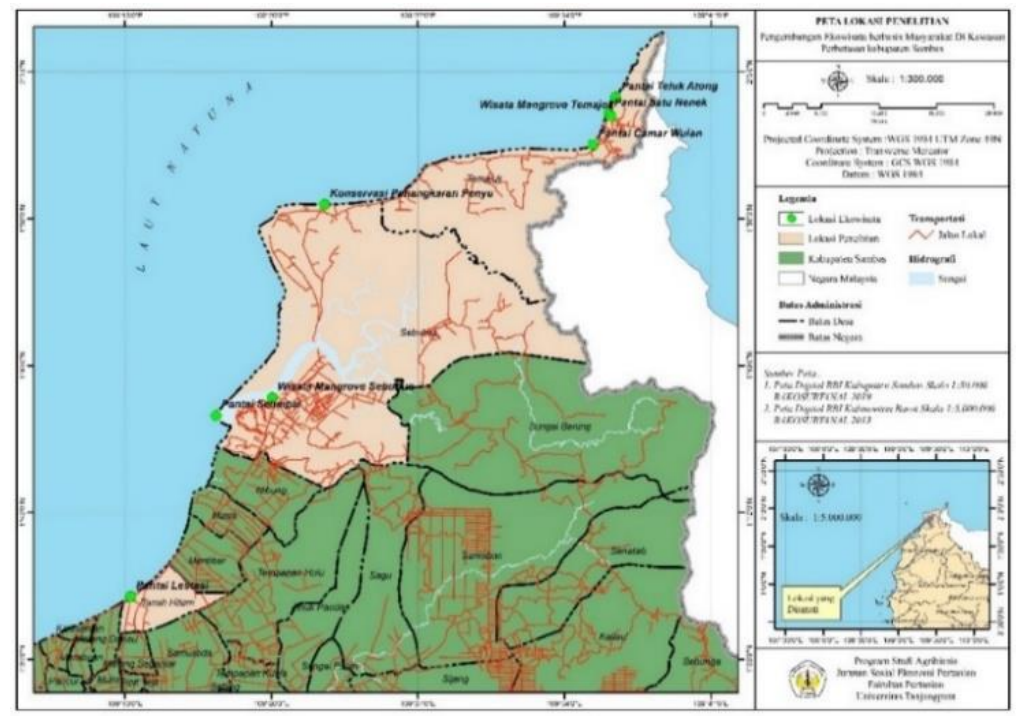

Figure 1. Study Location

\section{Picture Information:}

Peta Lokasi Penelitian : Study Location Map

Pengembangan Ekowisata Berbasis Masyarakat Di Kawasan Perbatasan Kabupaten Sambas: The Development Of Community-Based Ecotourism In Border Area Of Sambas Regency

Legenda =Legend

Transportasi $\quad=$ Transportation

Lokasi Ekowisata $=$ Ecotourism Site

Jalan Lokal $\quad=$ Local Road

Lokasi Penelitian =Study Location

Hidrografi =Hydrography

Kabupaten Samba =Samba Regency

Sungai =River

Negara Malaysia = Malaysia

Batas Administrasi $=$ Administration Border

Batas Desa $\quad=$ Village Border

Batas Negara =Country Border

Sumber Peta = Map Source

Sumber $\quad=$ Source

Program Studi Agribusiness =Agribusiness Department

Jurusan Sosial Ekonomi Pertanian =Agricultural Social-Economy School

Fakultas Pertanian =Agricultural Faculty

Universitas Tanjungpura =Tanjungpura University

Sambas Regency located in the northern part of West Borneo Province. Sambas regency occupied as much as $6,395.70 \mathrm{~km} 2$ or covered $4.36 \%$ from West Borneo Province. This study conducted in Paloh District that consisted of three villages: Tanah Hitam, Sebubus, and Temajuk. Paloh District was chosen as the study location due to some reasons: 1). Their ecotourism offered the natural beauty of nature, uniqueness, and biological diversity such as ecosystem, culture, beach, turtle, and mangrove 2). Low community income, 3). Located on the border area of 
Indonesia - Malaysia, and 4). There were three main local tribes domiciled in this district (Melayu, Dayak, and China).

To select the study participant, a purposive sampling technique which was defined as a sampling technique used to choose participants based on the researcher criteria, was applied in this study (Muhammad, 2009). The number of participants in this study was determined by the statement stated by (Gujarati, 2007) which explained that the minimum number of participants in a study was thirty participants. The participants were the key informants (Sambas Regency Tourism Board, Development Planning Agency, WWF member, and community figure/leader) and main informant (local people and visitors). This study conducted in three villages in Paloh District, Sambas Regency, they are Tanah Hitam, Sebubus, and Temajuk.

The Analytic Hierarchy Process (AHP) was used to identify the ecotourism developmental goal in improving community income in the border area of Sambas Regency. The criteria used were environmental, economy, social, and facility.

\section{RESULT AND DISCUSSION}

\section{Participant's Characteristic}

The data obtained from 30 key participants spread in all ecotourism sites in the border area. The participants were Sambas Regency Tourism Board, Development Planning Agency, WWF member, community figure/leader, local people, and visitors. The participant's characteristics observed in this study were gender, participant's age, education level, marriage status, occupation, and income.

The majority of participants were male (66.67\%). This could be due to the higher level of knowledge about ecotourism in the border area of the male participant. The participant also dominated by the age of 15-22 years of age (50\%). Participants in this range of age usually more productive in visiting various ecotourism sites in the border area. On the education level characteristic, the most participant was graduated from senior high school $(43.33 \%)$. The education level was the most important characteristic because it contributed a social mission in improving the awareness of the environment preservation and impact of a miss-planning on the implementation of a program. Higher levels of knowledge produced a higher level of productivity, therefore a higher level of knowledge also closely related to the higher level of community income.

On the marriage status characteristic, most participants were already married (60\%). The participants who mostly involved were the key informant, not the visitors. According to the occupation characteristic, 12 participants was working as a private entrepreneur, $40 \%$ participant were working as fisherman, farmer, souvenir seller, and run a small-scale business. Sometimes some participants were also working as jellyfish fisherman.

\section{The Determination of Pairwise-Weight Comparison Between Criteria}

The initial step in this study was determining the weight for each criteria used: environmental, economy, social, and facility. The determination of weigh in each criteria done by filling the pairwise comparison matrix. 


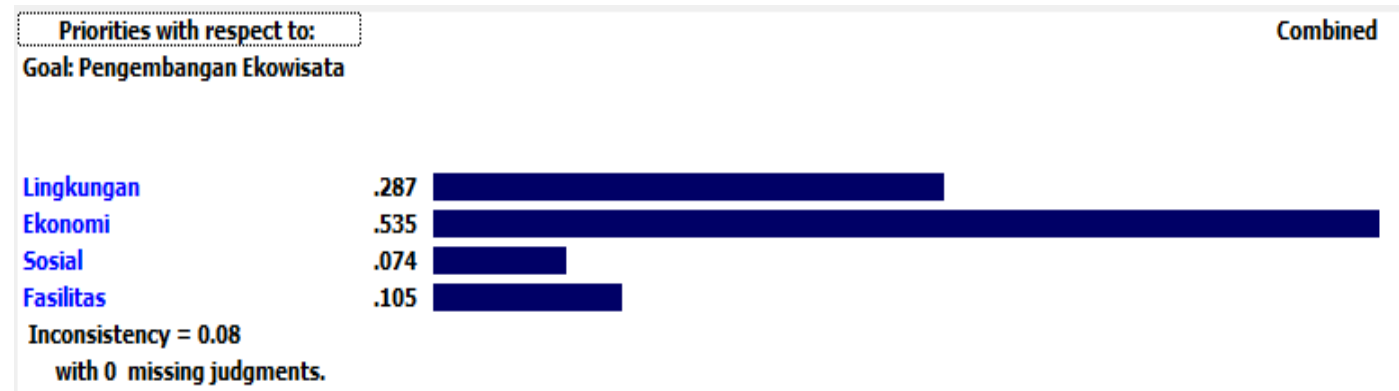

Figure 2. Pairwise-Weight Comparison between Criteria Normalization Matrix Graphic

Source: Analysis Result, 2019

Picture Information:

Priorities with respect to:

Goal: Pengembangan Wisata=Goal: Ecotourism Development

Lingkungan =Enviromental

Ekonomi =Economy

Sosial $\quad=$ Social

Fasilitas $\quad=$ Facility

Inconsistency $=0.08$

With 0 missing judgements.

The result revealed that the economy criteria had the highest weight with a total of 0.535 . This happened due to the significant role of the tourism sector in the national economic growth and the positive impact on the local community. Ecotourism development were also absorbing more workers that finally could reduce the number of unemployment community and improve their income and wellness. The community used this opportunity to sell the traditional culinary and souvenir around the site in Paloh District.

The Determination of Pairwise-Weight Comparison on Enviromental Criteria

Priorities with respect to:
Goal: Pengembangan Ekowisata."
>lingkungan

ekosistem
pencemaran
Inconsistency $=0$.
with 0 missing judgments.

Combined

Goal: Pengembangan Ekowisata

Combined

(ombined

Figure 3. Pairwise-Weight Comparison on Enviromental Criteria Normalization Matrix Graphic

Source: Analysis Result, 2019 
Picture Information

Priorities with respect to:

Goal Pengembangan Wisata=Goal: Ecotourism Development

$>$ Lingkungan $=>$ Enviromental

Ekosistem $=$ Ecosystem

Pencemaran $=$ Pollution

Inconsistency $=0.0$

With 0 missing judgements.

The ecosystem obtained the highest weight (0.750) due to the reciprocal correlation between the living thing and the environment inside it. A study was done by (Sabahan \& Evita, 2017) that aimed to know the landscape planning on community-based ecotourism in the coastal area of West Borneo revealed that Paloh District had unique and attractive coastal ecotourism sites. The role of local and national government were required to create resilience ecotourism site. Training sessions to improve community awareness about their role in managing the ecotourism site was urgently needed.

Ecosystem Sub-Criteria: Paloh District a beach/coastal area with specific characteristics of beach ecotourism, the transition between the land and sea ecosystem. The beach in Paloh District also consisted of rich biological diversity, especially mangrove and turtle. Studied from the land use aspect, the most beach ecotourism site was still in the natural state. Generally, this area consisted of sand, stones, mangrove, and turtle which ascend to the beach every night.

Pollution Sub-Criteria: Criteria that showed the water quality studied from the environmental aspect that related with the local community was the water purity. Results from the observation showed that the purity of the water affected by the content of mud. Ecotourism sites located near the big river estuaries usually contained more mud (Tanah Hitam and Selimpai Beach). The low river current brought the mud to the beach. The situation was a little bit different on the Belacan, Camar, and Tanjung Datok beach. These beaches dominated by white sand and stones, hence the mud could reach the seafloor.

\section{The Determination of Pairwise-Weight Comparison on Economy Criteria}

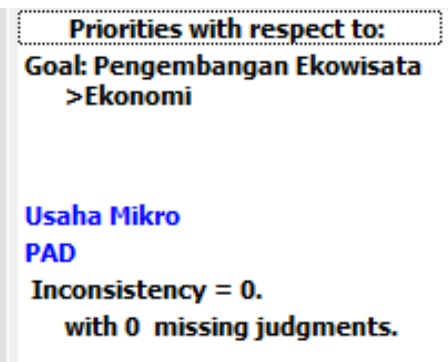

Figure 4. Pairwise-Weight Comparison on Economy Criteria Normalization Matrix Graphic 
Picture Information

Priorities with respect to:

Goal Pengembangan Wisata = Goal: Ecotourism Development

$>$ Ekonomi

Usaha Mikro

$=>$ Economy

PAD

$=$ Micro-Business

Inconsistency

$=$ Original Local Government Revenue

$=0$.

With 0 missing judgements.

The micro-business obtained the highest weight with a total of 0.749 . (Yulianda, 2011) defined ecotourism as a tour to tourism sites that preserving the nature and building the wellness of the community around the site. According to this definition, the ecotourism was highly promoting the small scale-business such as micro small medium enterprise and preserving the environmental/social-cultural.

Micro-Business Sub-Criteria: Cooperation between the local community was the main subject requires to control the resources in the ecotourism sites. There were various types of micro-business in the study location, such as food, souvenir, water-taxi, guide, and homestay-business. This micro-business was effective in improving their income.

Original Local Government Revenue Sub-Criteria: The local stakeholder (Sambas Regency Development Planning Agency) was the key stakeholder that majorly contributed in taking decisions related to the development of ecotourism in Paloh District. The Sambas Tourism Board expected to make proper policies about community participation in the development of ecotourism in the Sambas Regency. The ecotourism sites in Sambas Regency did not optimally developed due to the lack of funds and infrastructures. If the ecotourism sites managed well, the profit obtained could increase the original local government revenue.

\section{The Determination of Pairwise-Weight Comparison on Social Criteria}
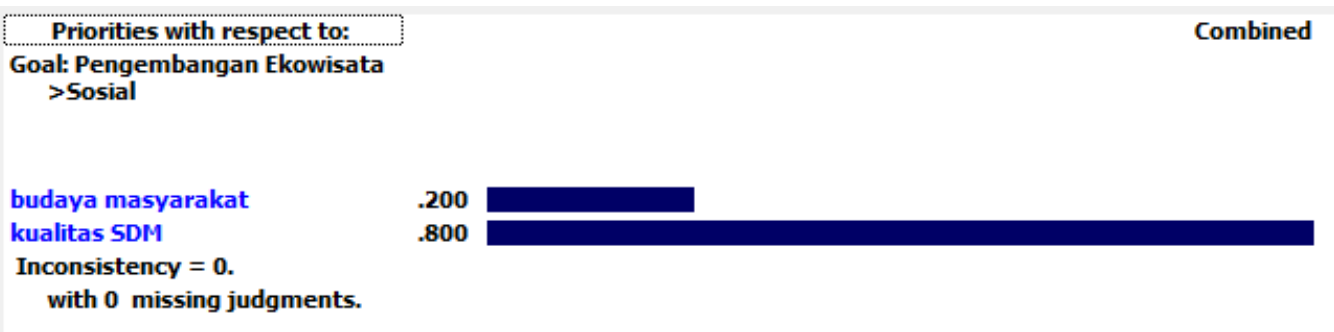

Figure 5. Pairwise-Weight Comparison on Social Criteria Normalization Matrix Graphic

Source: Analysis Result, 2019

Picture Information

Priorities with respect to:

Goal Pengembangan Wisata=Goal: Ecotourism Development

$>$ Sosial $\quad \Rightarrow$ Social

Budaya Masyarakat = Community Culture

Kualitas SDM = Human Resource Quality

Original Local Government Revenue 
Inconsistency $\quad=0.00$

With 0 missing judgements

The human resource quality had the highest weight with a total of 0.667 . Local community must be actively involved as the main subject in the ecotourism development and the government must be built a good partnership with the local community. Local communities had a complete understanding of the ecotourism in their environment. They were also capable of providing a proper solution to improve the ecotourism sites. According to a study done by (Pratiwi \& Pinasti, 2017), all local community (community figure/leader, youth organization (Karang Taruna), tourism awareness group, and other local community) could contribute to the ecotourism management. The impact of tourism activities revealed by the change of some cultural elements such as the community knowledge development, the emersion of the new occupation, the introduction of language diversities, technological advancements, the improvement of hospitality levels, increasing cooperation, and the emergence of horizontal conflicts between local communities.

Human Resource Quality: Human resources was an important factor in developing ecotourism sites. Improving the human resources and skills in the ecotourism sites was a basic requirement in a community-based ecotourism development (Priono, 2012). Local community participation in ecotourism development was the community involvement on the emotional, psychological, and physical aspects to build their responsibility in improving the community wellness in Paloh District. The comprehensive understanding of the local community about their ecotourism sites given valuable information for the ecotourism development.

Community Culture: Culture was a tradition resulted from the transferred information from generation to generation through written and oral ways, without this tradition, the community culture could become extinct. Study by (Sugiyarto \& Amaruli, 2018) entitled "Cultural and Local Genius-Based Ecotourism Development" stated that cultural destination and local geniuses in tourism development were the part of human creativity that has economic value. Antar ajong culture was a sambasmalay community local tradition in Paloh District. This cultural tradition done to assure a good harvesting period and avoid the damage of the harvested product because of the pest attack. Antar ajong was also seasonal cultural tourism that periodically showed in Lestari Beach to attract tourists.

\section{Determination of Pairwise Weight Comparison on the Facility Criteria}

The highest weight in these criteria obtained by the infrastructure sub-criteria with a total of 0.594. (Calderon \& Serven, 2014) in their study entitled "The Effects of Infrastructure Development on Growth and Income Distribution" also stated that the improvement of infrastructure was a significant part to build an area rapidly. Infrastructures undeniably impacted the development of certain aspects of the national growth. The limited amount of infrastructure provided in the ecotourism site in Paloh District highly contributed to the slow tourism activities in those border areas. 


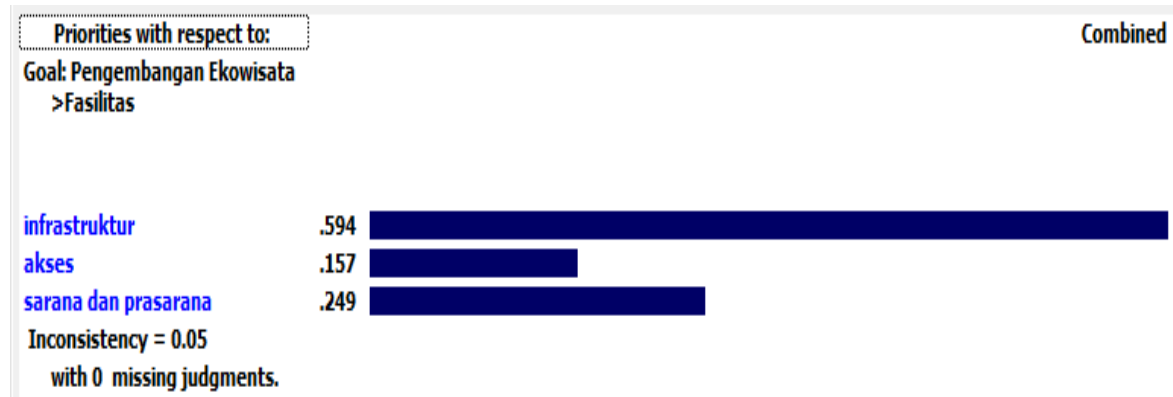

Figure 6. Pairwise Comparison on the Facility Criteria Normalization Matrix Graphic

Source: Analysis Result, 2019

Picture Information

Priorities with respect to:

Goal Pengembangan Wisata=Goal: Ecotourism Development

$>$ Fasilitas $\quad=>$ Facility

Infrastruktur = Infrastructure

Akses $\quad=$ Access

Sarana Prasarana= Supporting Facillity

Inconsistency $\quad=0.05$

With 0 missing judgements.

Infrastructure Sub-Criteria: infrastructure was an important part to develop ecotourism site. The physical elements such as bridges, clean water, telecommunication network, and electricity were the basic infrastructure required to improve the ecotourism site.

Accessibility Sub-Criteria: most villages in Paloh District already have good local access roads and could be reached by the four-wheel transportation. Temajuk Village was the only one village whose main road made of yellow soil. The village located $45 \mathrm{~km}$ away from the center of Paloh District. This type of soil was relatively slippery in the rainy season and very dusty in the dry season

Supporting Facillity: Electricity could be properly used by six villages in Paloh District. Temajuk Village was the only village that used electricity produced by a diesel power electric generator. This diesel generator only operated in the night (17.00-05.00) to save the fuel used to operate the generator. The fuel must be well utilized because of the remote location of the village and difficulty in gaining the fuel. Temajuk village also the only village that didn't get proper clean water from the municipal waterworks. 


\section{Determination of Pairwise Alternative Weight Comparison}

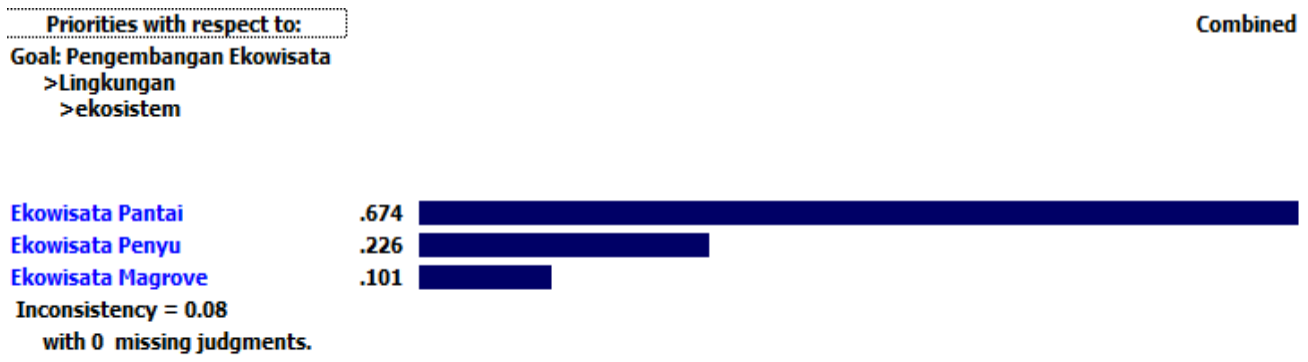

Figure 7. Enviromental Alternative Pairwise-Comparison (Ecosystem) Matrix Normalization Graphic Source: Analysis Result, 2019

Picture Information:

Priorities with respect to:

Goal Pengembangan Wisata

$>$ Lingkungan

$=$ Goal: Ecotourism Development

$>$ Ecosystem

$=>$ Environment

$=>$ Ecotourism

Ekowisata Pantai

Ekowisata Penyu

$=$ Beach Ecotourism

Ekowisata Mangrove

$=$ Turtle Ecotourism

Inconsistency

$=$ Mangrove Ecotourism

$=0.08$

With 0 missing judgements.

The beach ecotourism prioritized in this criteria (0.674). The development of the beach ecotourism done to utilize the coastal ecosystem in improving the community economic status. Therefore, the beauty of the ecosystem diversity in the Paloh District must be well preserved.

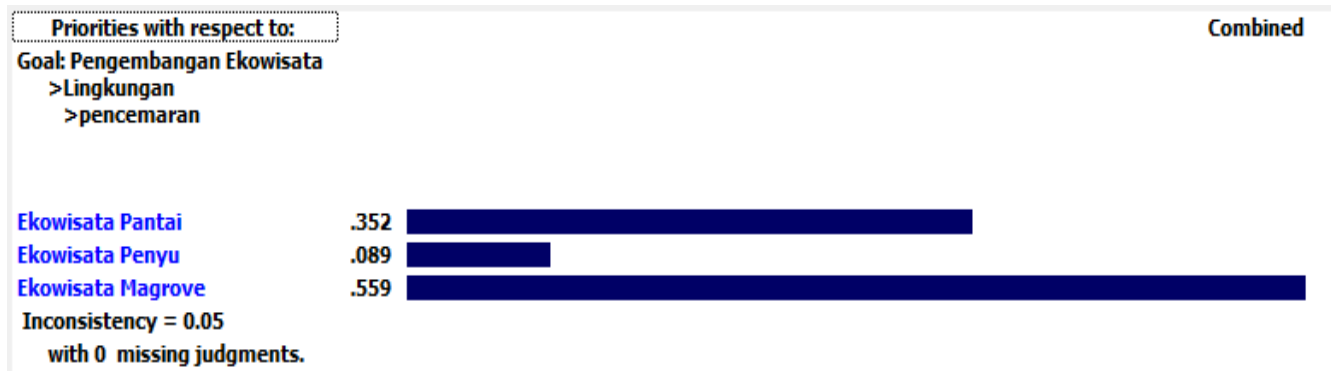

Figure 8. Enviromental Alternative Pairwise-Comparison (Pollution) Matrix

Normalization Graphic

Source: Analysis Result, 2019

Picture Information:

Priorities with respect to:

Goal Pengembangan Wisata

$>$ Lingkungan

$=$ Goal: Ecotourism Development

$>$ Pencemaran

$=>$ Environment

$=>$ Pollution

Ekowisata Pantai

$=$ Beach Ecotourism

Ekowisata Penyu

$=$ Turtle Ecotourism 
Ekowisata Mangrove =Mangrove Ecotourism

Inconsistency $\quad=0.05$

With 0 missing judgements

In the pollution sub-criteria, the highest weight obtained by the mangrove ecotourism (0.559). The mangrove ecotourism in Sebulus and Temajuk Village, Paloh District haven't well managed by the local community and stakeholder. The supporting facilities (ex. trash bin) didn't properly provided around the ecotourism site. This condition made the sites seemed less attractive to be visited.

Priorities with respect to:
Goal: Pengembangan Ekowisata
>Ekonomi
>Usaha Mikro
Ekowisata Pantai
Ekowisata Penyu
Ekowisata Magrove
Inconsistency = 0.07
with 0 missing judgments.

Combined

.614

.268

.117
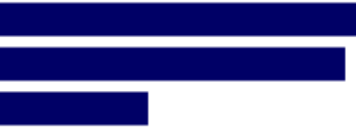

Figure 9. Economic Alternative Pairwise-Comparison (Micro-Business) Matrix Normalization Graphic

Source: Analysis Result, 2019

Picture Information

Priorities with respect to:

Goal Pengembangan Wisata

$>$ Ekonomi

> Usaha Mikro

Ekowisata Panta

Ekowisata Penyu

Ekowisata Mangrove

Inconsistency

$=$ Goal: Ecotourism Development

$=>$ Economy

$=>$ Micro-Business

$i=$ Beach Ecotourism

$=$ Turtle Ecotourism

$=$ Mangrove Ecotourism

$=0.07$

With 0 missing judgements.

This study showed that the type of ecotourism prioritized in Paloh District, West Borneo was the beach ecotourism $(0,614)$. The beach ecotourism in Paloh District spread in three villages: Tanah Hitam, Sebubus, and Temajuk. Interview done on some key informants revealed that most visitors were spending their time on the beach due to the natural beauty offered by the beach and the "heaven in the tail of Borneo" nickname given to the beaches in Paloh district. The local community positively responded to the ecotourism site development. Their enthusiasm showed through the opening of some small food businesses operated by the local communities around the ecotourism site. 


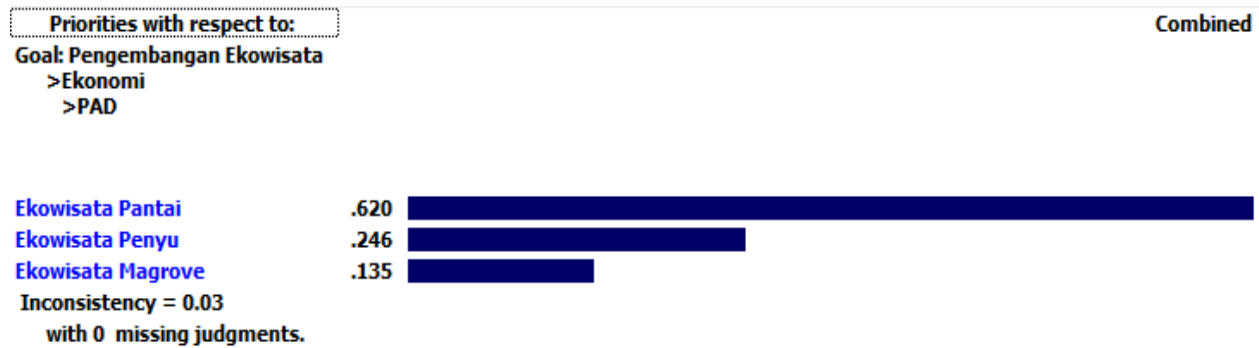

Figure 10. Economic Alternative Pairwise-Comparison (Original Local Government Revenue) Matrix Normalization Graphic

Source: Analysis Result, 2019

Picture Information

Priorities with respect to:

Goal: Pengembangan Ekowisata $=$ Goal: Ecotourism Development

$>$ Ekonomi $\quad \Rightarrow$ Economy

$>P A D>$ Original Local Government Revenue

Ekowisata Pantai = Beach Ecotourism

Ekowisata Penyu = Turtle Ecotourism

Ekowisata Mangrove = Mangrove Ecotourism

Inconsistency $\quad=0.05$

With 0 missing judgements

Ecotourism development was significant in maintaining national economic security because of the short duration demanded to increase the foreign exchange in a country. Paloh District in Sambas Regency was an area that has many attractive ecotourism sites. There were some beach ecotourism sites offered in Paloh District, but the most attractive beach ecotourism sites were located in Temajuk Village.

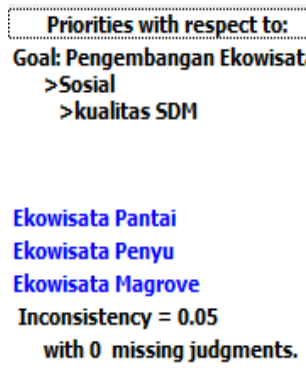

Combined

Figure 11. Social Alternative Pairwise-Comparison (Human Resource Quality) Matrix Normalization Graphic

Source: Analysis Result, 2019

Picture Information

Priorities with respect to:

Goal: Pengembangan Ekowisata =Goal: Ecotourism Development

$>$ Social $=>$ Social

$>$ Kualitas SDM

Ekowisata Pantai

Ekowisata Penyu

Ekowisata Mangrove

Inconsistency

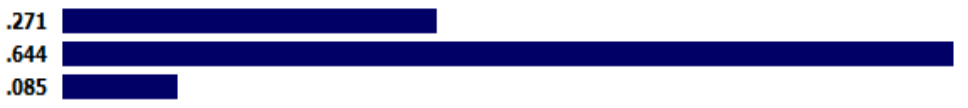

With 0 missing judgements

$=>$ Human resource quality

= Beach Ecotourism

= Turtle Ecotourism

$=$ Mangrove Ecotourism

$=0.05$ 
Human resource quality was the next factor that important to anticipate the negative impact of ecotourism development. The local community was the key stakeholder and the party who were accepting the direct impact of ecotourism development. Reviewed from the social-subcriteria, the turtle ecotourism was being prioritized (0.547) due to the low level of knowledge of the importance of turtle preservation effort.

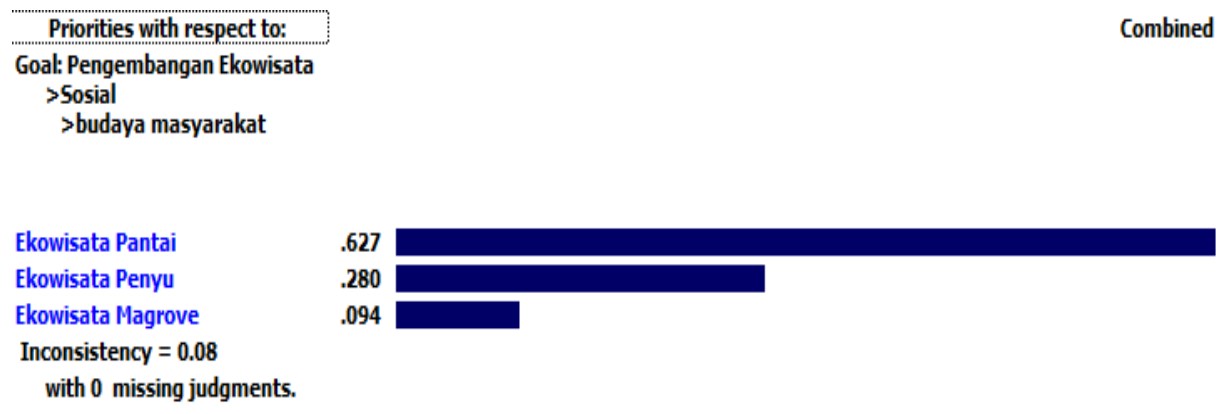

Figure 12. Social Alternative Pairwise-Comparison (Community Culture) Matrix Normalization Graphic Source: Analysis Result, 2019

Picture Information

Priorities with respect to:

Goal: Pengembangan Ekowisata =Goal: Ecotourism Development

$>$ Sosial $=>$ Social

$>$ Budaya Masyarakat $\quad$ =>Community Culture

Ekowisata Pantai = Beach Ecotourism

Ekowisata Penyu = Turtle Ecotourism

Ekowisata Mangrove = Mangrove Ecotourism

Inconsistency $\quad=0.08$

With 0 missing judgements.

Results revealed that the community cultural alternative prioritized the beach ecotourism (0.672). The community stated that antar ajong culture was a unique charm that attracts the tourist to visit the beach in Paloh district. This culture performed by the local community on the beach, especially in Lestari Beach that located in Tanah Hitam and Temajuk Village.

\begin{tabular}{|c|c|c|}
\hline & & Combined \\
\hline \multicolumn{3}{|l|}{$\begin{array}{l}\text { Goal: Pengembangan Ekowisata } \\
\text { > Fasilitas } \\
\text { >infrastruktur }\end{array}$} \\
\hline Ekowisata Pantai & .661 & \\
\hline Ekowisata Penyu & .272 & \\
\hline $\begin{array}{l}\text { Ekowisata Magrove } \\
\text { Inconsistency }=0.04\end{array}$ & .067 & \\
\hline
\end{tabular}

Figure 13. Facility Alternative Pairwise-Comparison (Infrastructure) Matrix Normalization Graphic Source: Analysis Result, 2019

Picture Information

Priorities with respect to: 
Goal: Pengembangan Ekowisata =Goal: Ecotourism Development

$>$ Fasilitas $=>$ Facility

$>$ Infrastruktur $=>$ Infrastructure

Ekowisata Pantai = Beach Ecotourism

Ekowisata Penyu = Turtle Ecotourism

Ekowisata Mangrove = Mangrove Ecotourism

Inconsistency $=0.04$

With 0 missing judgements

Tourism infrastructures were vital in improving local economic growth. The government should prioritize the infrastructure construction on the national development planning to improve the national quality and quantity of infrastructures.

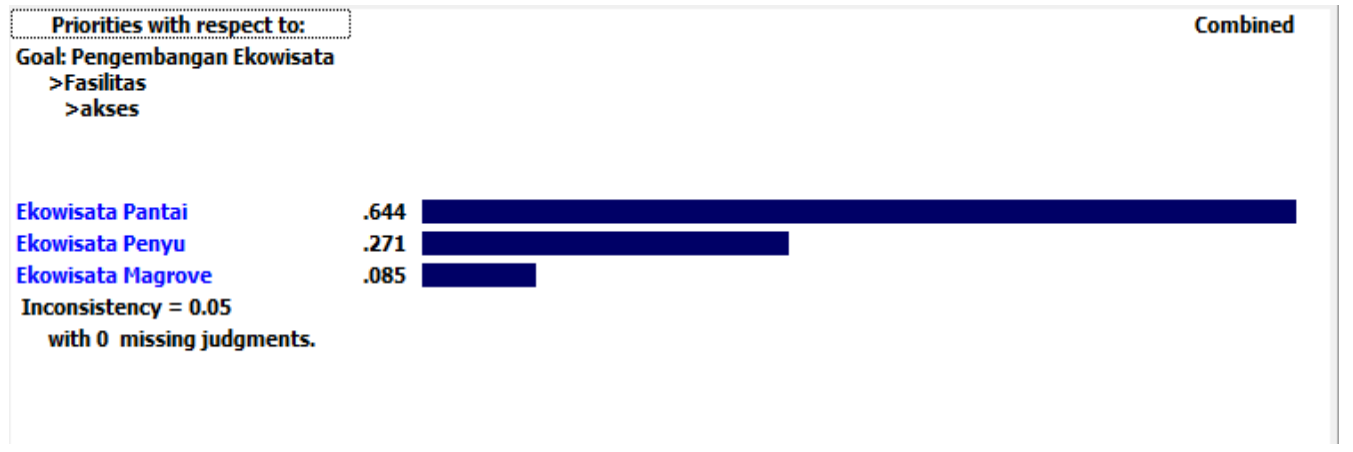

Figure 14. Facility Alternative Pairwise-Comparison (Accesibility) Matrix

Normalization Graphic

Source: Analysis Result, 2019

Picture Information

Priorities with respect to:

Goal: Pengembangan Ekowisata $=$ Goal: Ecotourism Development

$>$ Fasilitas

$>$ Akses

$=>$ Facility

Ekowisata Pantai

$=>$ Access

Ekowisata Penyu

$=$ Beach Ecotourism

Ekowisata Mangrove

$=$ Turtle Ecotourism

Inconsistency

=Mangrove Ecotourism

$=0.05$

With 0 missing judgements.

To access beaches in three villages in Paloh District (Tanah Hitam Village, Sebubus Village, and Temajuk Village), the community or tourist used land and water transportation. The duration needed to access the beaches using land transportation (car or motorcycle) was 5-6 hours due to the inadequate local road (still made of soil). 


Priorities with respect to:
Goal: Pengembangan Ekowisata
$>$ Fasilitas
$>$ sarana dan prasarana

Ekowisata Pantai
Ekowisata Penyu

Figure 14. Facility Alternative Pairwise-Comparison (Supporting Facillity) Matrix Normalization Graphic Source: Analysis Result, 2019

Picture Information

Priorities with respect to:

Goal: Pengembangan Ekowisata =Goal: Ecotourism Development

$>$ Fasilitas

> Sarana dan Prasarana

$=>$ Facility

$=>$ Infrastructure

Ekowisata Pantai

= Beach Ecotourism

Ekowisata Penyu

$=$ Turtle Ecotourism

Ekowisata Mangrove

Inconsistency

$=$ Mangrove Ecotourism

$=0.04$

With 0 missing judgements.

The supporting facilities/infrastructures in the beach ecotourism prioritized to properly built (0.611) due to the high number of tourist visitation at each year. The barrier found during the ecotourism development in the Paloh district was inadequate ecotourism infrastructures, especially in the Temajuk Village. No proper crossing border posts and good telecommunication networks provided by the ecotourism sites.

The Determination of Ecotourism Development Priority Scale by Using the Analytic Hierarchy Process (AHP)

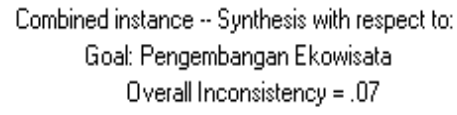

Ekowisata Pantai

Ekowisata Penyu

Ekowisata Magrove

Figure 15. Priority Scale Matrix Normality Analysis Source: Analysis Result, 2019

Picture Information

Combined instance-Synthesis with respect to:

Goal: Pengembangan Ekowisata

Overall Incosistency

$=$ Goal: Ecotourism Development

Ekowisata Pantai

$=0.07$

Ekowisata Penyu

=Beach Ecotourism

Ekowisata Mangrove

$=$ Turtle Ecotourism

=Mangrove Ecotourism 
This calculation was the final result of the ecotourism development selection toward the improvement of community income in the border area. The beach ecotourism obtained the highest weight $(0.593)$ followed by the turtle ecotourism and mangrove ecotourism with a total weight of 0.260 and 0.147 , respectively. Result also showed that the priority factor was the economy factor with the total weight of 0.535. Some small-scale food businesses were actively operating around the ecotourism sites that finally contributed to the local community income. The number of local or international tourists in the beach ecotourism site also remained constant during the weekend or national holiday.

\section{CONCLUSION}

According to the result, we concluded the factors that need to be considered to improve ecotourism sites in the Sambas Regency border area were the environment, economy, accessibility, and facility factor. Statistical analysis showed that the economic factor was having the highest weight with a total of 0.535 , followed by the environmental, facility, and social factors with a total of $0.287,0.105$, and 0.074 respectively. Some ecotourism sites such as beach, turtle, and mangrove ecotourism also potentially developed as alternative tourism sites. Results showed that beach ecotourism ranked in the first place, followed by turtle ecotourism and mangrove ecotourism with a total weight of $0.593,0.260$, and 0.147 respectively.

\section{RECOMMENDATION}

Based on the result and conclusion, we suggest the improvement of infrastructures in the ecotourism sites. Some roads to access the ecotourism already well built, but some ecotourism site's accesses were still made from soil. The condition of these site's accesses made the visitors and community couldn't visit the ecotourism sites during the rainy season. The gazebos, toilets, places to rinse, and mosques also must be built in the ecotourism sites. During the study, the visitor who desired to use those facilities must go to some restaurants or local people home. An improvement on the promotional activities also must be addressed. Promotional activity could be done using pamphlets media that consisted of complete information about certain ecotourism sites or social media platforms. This promotional activity would disseminate the unique characteristic of the ecotourism sites and bring a significant improvement on the community income and wellness. Synergy between the local, national, and community must be well maintained to improve the quality of tourism sites offered in the national or international level.

\section{REFERENCES}

Calderon, \& Serven. (2014). The Effects of Infrastructure Development on Growth and Income Distribution. Journal of Econometrics, 485-502.

Gujarati, D. N. (2007). Dasar-Dasar Ekonometrika. Jakarta: Erlangga.

Muhammad, F. (2009). Metode Penelitian Kuantitatif. Semarang: Walisongo Press. 
Naisbitt, \& Jhon. (1994). Global Paradox. Jakarta Indonesia: penerbit Binapura Aksara.

Pratiwi, B. D., \& Pinasti, I. S. (2017). Pariwisata dan Budaya (Studi Peran Serta Masyarakat Lokal dalam Pengelolaan Pariwisata di Kampung Pitu, Nglanggeran, Patuk, Gunung Kidul). Jurnal Pendidikan Sosiologi.

Priono. (2012). Pengembangan Kawasan Ekowisata Bukit Tangkiling Berbasis Masyarakat. Jurnal Perspektif Arsitektur, Volume 7 No 1.

Qomariah, L. (2009). Pengembangan Ekowisata Berbasis Masyarakat Di Taman Nasional Meru Betiri. Bogor: Institut Pertanian Bogor.

Sabahan, \& Evita, R. (2017). Zonasi Lanskap Ekowisata Pesisir Kecamatan Paloh Kalimantan Barat. E-Jurnal Arsitektur Lanskap, vol 3, 42-38.

Sugiyarto, \& Amaruli, R. J. (2018). Pengembangan Pariwisata Berbasis Budaya dan Kearifan Lokal. Jurnal Administrasi Bisnis, 7, 45-52.

Wunder. (2000). Ecoturism and economic intensive - an empirical approach. DasarDasar Ekowisata. Edisi Pertama. Cetakan Pertama. Jawa Timur: Bayumedia Publishing.

Yulianda, F. (2011). Ekowisata Bahari Sebagai Alternatif Pemanfaatan sumberdaya pesisir berbasis konservasi. Jurnal Agribisnis, 3, 192-199. 